\title{
The Development and Challenges of Football Sport in Some Selected Woredas of North Showa Zone
}

\author{
Tewodros Abir, Alemayehu Ejigu, Arefayne Mesfin \\ Collage of Natural and Computational Science, Sport Science Department Debre Birhan University, Debre Birhan, Ethiopia
}

Email address:

wahidteddy@gmail.com (T. Abir)

\section{To cite this article:}

Tewodros Abir, Alemayehu Ejigu, Arefayne Mesfin. The Development and Challenges of Football Sport in Some Selected Woredas of North Showa Zone. American Journal of Sports Science. Vol. 5, No. 6, 2017, pp. 40-44. doi: 10.11648/j.ajss.20170506.11

Received: November 6, 2017; Accepted: November 16, 2017; Published: December 12, 2017

\begin{abstract}
The purpose of this study was to identify the development and challenges of football in some selected weredas of North Showa Zone. The subject in this study were 282 players 15 coaches' 6 wereda sport officers and 4 zone sport officers selected from the total population of 940,48 and 10 respectively. A descriptive survey study is used. As a methods of data gathering tools; questionnaire, interview, and document analysis were employed. To analyze the collected data, both qualitative and quantitative methods were used. Results of the study revealed that village is the main sources of youth football players for the woredas, Schools have been the main sources of potential coaches for teams. The major constraints associated with North Showa Zone football sport are found to have very low media coverage, absence of supporters' association, a few number of spectators, only one club, lack of facilities and equipment, no regular salary for coaches and players, lack or absence of play field in the villages, not following scientific method of training by coaches and very low level of communication among stakeholders. To overcome these, every stakeholder should work hand to hand in order to solve the problems.
\end{abstract}

Keywords: Football Sport, Projects, Stakeholders, Supporters’ Association, Villages

\section{Introduction}

Sport is widely regarded as having significant social, health and economic benefits. In contemporary political discourse, sport is being analyzed not only in terms of its economic impact but also in terms of its potential to combat poverty, unemployment, crime and segregation. Sport is believed to serve as a vehicle for the empowerment and social connection of 'vulnerable' young people living in underprivileged urban neighborhoods. In particular, it has been argued that the social benefits of sport extend to spheres that are hard to reach through more traditional, political and social activities (Seefeldt, Ewing and Walk 1992). Even if it has countless values and benefits this game is not well developed in our country because of different problems and challenges.

The limited role of the community in sports, the decline of sports in schools, the shortage of sports facilities, sport wear and equipment as well as the lack of trained personnel in the sphere have also made the problem more complex (National sport policy, 1998)

Therefore, this research was designed to identify those challenges and a problem that hinders the development of football in particular to some selected towns of North Showa Zone.

The specific objectives of the study are to identify how the football training is practice, to identify the major factors that affects the development of football in North Showa Zone?, to identify the historical development of football in North Showa Zone; to provide possible suggestion to improve the number and capacity of woredas and to encourage the interests of other researcher to conduct research on the same issues as to find out solution for North Showa Zone football development.

To this end, the study tries to answer the following basic research questions.

1. In what ways the actual football training is practiced?

2. What are the major hindering factors that affect the development of football in NSZ?

3. To what extent facilities and equipment are available?

4. To what extent these hindering factors affect the development of football in NSZ?

5. What are the historical developments of football in North Showa Zone? 
6. What possible solutions should be carried out to solve the problem?

This study would be adjusted in the direction to identify the development and challenges of North Showa Zone football programs. The researchers of this study hopes that the findings of the study would contribute to: give insight for North Showa Zone sport secretarial, woredas sport secretarial, media, clubs' and administrators to enhance their practice; give insight for officials, coaches and other stakeholders will have better knowledge of the core problems; and Initiate other researchers to conduct further and detailed study on the development of football program in North Showa Zone.

\section{Materials and Methods}

Based on the information obtained from North Showa Zone sport office in 2014 G. C. both towns and woredas were purposely chosen for the study. That is North Showa Zone (Showa Robit Town, Eferata and Gidem woreda, Meniz Gera woreda, Debre Birhan Town, Merhabete woreda, and Antsokiya Gemiza woreda).

The research methodology used in this descriptive survey study is a triangulation of different related research techniques, which refers to a combination of mainly qualitative and quantitative methods of data collection and analysis. This process involves the "mixing of mainly qualitative and quantitative methods of data analysis". The two styles have different complementary strengths and a study that employs both is fuller and comprehensive" The negatives of one method are negated by the positives of the other method (Neuman; 2000).

Data in this study was generated through a survey using a questionnaire administered to 297 project players, yearly participants, and coach respondents in the age range 13 to 40 years to quantify the development and challenges of football in north Sowa zone.

Ten (10) interviews with key informants from the Woreda officers, and North Showa Zone sport offices about the development and challenges of football in north Sowa zone

In North Sowa Zone there are 24 woredas and 3 towns out of them 4 woredas and 2 towns are selected based on the information get from North Sowa Zone sport office. As a result, a total of 940 players and 48 coaches are involved under these selected woreda and town. Accordingly, 282 (30\%) out of 940 players, $15(30.4 \%)$, out of 48 coaches were selected for this study. Moreover, $6(100 \%)$ out of 6 woreda officers and $4(40 \%)$ out of 10 Zone sport officers were considered in this study too.

In order to select sample from the target population, the researchers adapted simple random and purposive sampling strategies. Simple random sampling method was employed as of selecting players while purposive sampling method was employed for selecting coaches, woreda sport officers and zone sport officers.

Data analysis of the questionnaires in this study is concerned with reducing masses of quantitative data to meaningful information. The questionnaire schedule was coded and a data matrix form created using the SPSS computer package. An analysis framework was then developed using the SPSS package which categorizes variables according to their measurements variables was then classified according to objectives of the study in order to address the study's objectives. Qualitative data analysis and bivariate analysis (using cross tabulations) were employed.

Underlying the analyses of all data is the overarching functionalist theoretical perspective and related theories which serve as tools of analysis and explanation of findings.

The results obtained from the questionnaire, interview, and documents are presented in table and analyzed. Data obtained from the close-ended questionnaires were analyzed quantitatively by using statistical methods such as Frequency Counts, Percentage, Mean, Standard deviation, and the t-test. Whereas Data obtained from open-ended questionnaires and the interview guide were analyzed qualitatively. In addition to this documents were used to triangulate the responses.

\section{Result}

Table 1. Affecting factors of football sport in North Showa zone like media coverage, supporter association and spectators.

\begin{tabular}{|c|c|c|c|c|c|c|}
\hline \multirow{3}{*}{ Item } & \multicolumn{6}{|c|}{ Respondents' response } \\
\hline & \multicolumn{3}{|c|}{ Players } & \multicolumn{3}{|l|}{ Coaches } \\
\hline & Yes & No & Total & Yes & No & Total \\
\hline Do you believe that football sport in your zone has appropriate media coverage? & $71(25.2)$ & $211(74.8)$ & $282(100)$ & $1(6.7)$ & $14(93.3)$ & $15(100)$ \\
\hline Does your team/project have supporter (sympathizer) association? & $71(25.2)$ & $211(74.8)$ & $282(100)$ & $2(13.3)$ & $13(86.7)$ & $15(100)$ \\
\hline Do football matches in your town have spectators? & $212(75.2)$ & $70(24.8)$ & $282(100)$ & $12(80)$ & $3(20)$ & $15(100)$ \\
\hline Do spectators in your woreda/town pay fee to watch football game or not? & $53(18.8)$ & $229(81.2)$ & $282(100)$ & $2(13.3)$ & $13(86.7)$ & $15(100)$ \\
\hline
\end{tabular}

Numbers in parenthesis indicate percentage

Asking football players and their respective coaches' do you believe that football sport in your zone has appropriate media coverage, the following results were obtained: the majority $93 \%$ and $74.8 \%$ of coaches and players respectively said that football sport in their zone has no appropriate media coverage. While 6.7 and 25.2 of coaches and players respectively said that football sport in their zone has appropriate media coverage.

According to the response gathered from open-ended questions asked for the same question, the vast majority of the respondents responded that football sport in their zone has no appropriate media coverage. The woreda/zone sport office has no chance to address competition programs and results to the society. Because of this the society who love football sport have no idea when, where and who have game, 
and also it minimize the chance of getting sponsors.

Thus, this response clearly implies that football sport in North Showa Zone has no media coverage. So this is also one of the biggest problems that contribute for the decline of football in North Showa Zone.

According to Eileen Kennedy and Laura Hills, (2009) stated that "Sport, which will not follow the media's wishes, will die gradually." According to Nicholson, M (2007) It is generally recognized that modern sport can no longer do without the media and vice-verso.

Regarding supporter (sympathizer), $86.7 \%$ and $74.8 \%$ of coaches and players respectively said that their team/project have no supporter (sympathizer) association. Whereas 13.3\% $25.2 \%$ of coaches and players respectively said that their team/project does have supporter (sympathizer) association.

According to the responses gathered from open-ended questions, asked for the same question, the vast majority of the respondents responded that their team has no supporter association. The absence of club supporter affects the number or magnitude of people who are expected to be funs of the sport. Having no access for sponsorship, this may affect in such a way that the sport may not be considered entertaining among the community.

Thus, this indicates that majority of coach and players have indicates that their team/project have no supporter (sympathizer) association. This could be one of the problems for the development of football in North Showa Zone.

Regarding spectators, $80 \%$ and $75.2 \%$ of coaches and players respectively replied that football competitions that are held in North Showa Zone have spectators. Whereas 20\% and $24.8 \%$ of coaches and players respectively replied that football competitions that are held in North Showa Zone have spectators.

Regarding spectators pay entrance fee $86.7 \%$ and $81.2 \%$ of coaches and players respectively replied that football competitions spectators get into the stadium without payment. Whereas $13.3 \%$ and $18.8 \%$ of coaches and players respectively replied that football competitions spectators get into the stadium with payment.

According to the responses gathered from open-ended questions, asked for the same question, the vast majority of the respondents responded that football competitions spectators get into the stadium without paying entrance fee because of this the woreda/zone sport office and football team lost the income from the entrance fee so they have no chance to fulfill the equipment that are important for training and competition.

Thus, this indicates that majority of respondents have indicates that football competitions spectators get into the stadium without payment. This could be one of the problems for the development of football in North Sowa Zone.

Table 2. Concerning about equipment and facilities.

\begin{tabular}{|c|c|c|c|c|c|c|}
\hline \multirow{3}{*}{ Item } & \multicolumn{6}{|c|}{ Respondents' response } \\
\hline & \multicolumn{3}{|c|}{ Players } & \multicolumn{3}{|l|}{ Coaches } \\
\hline & Yes & No & Total & Yes & No & Total \\
\hline Do you have transportation? & $39(13.8)$ & $243(86.2)$ & $282(100)$ & $2(13.3)$ & $13(86.7)$ & $15(100)$ \\
\hline Do you get enough equipment and facilities for training? & $66(23.4)$ & $216(76.6)$ & $282(100)$ & $2(13.3)$ & $13(86.7)$ & $15(100)$ \\
\hline $\begin{array}{l}\text { Does your zone provide you with the appropriate sportswear for training } \\
\text { and for competition separately? }\end{array}$ & $66(23.4)$ & $216(76.6)$ & $282(100)$ & $5(33.3)$ & $10(66.7)$ & $15(100)$ \\
\hline Does your woreda provide sufficient food after training and competition? & $51(18.1)$ & 231(81.9) & $282(100)$ & $2(13.3)$ & $13(86.7)$ & $15(100)$ \\
\hline
\end{tabular}

Numbers in parenthesis indicate percentage

Regarding transportation for training and competition, $86.7 \%$ and $86.2 \%$ of coaches and players respectively answered that they have no transportation that take them to training and competition place. Whereas $13.3 \%$ and $13.8 \%$ of coaches and players respectively answered that they do have transportation that takes them to training and competition place.

According to the responses gathered from open-ended questions, asked for the same question, the vast majority of the respondents responded that their team has no transportation that travel them to the training and competition place because of this players reach to the training or competition place when they exhausted so they cannot exercise or play to their level of best.

Regarding the availability of equipment and facilities $86.7 \%$ and $76.6 \%$ of coaches and players respectively replied that they do not have enough equipment and facilities for training. Whereas $13.3 \%$ and $23.4 \%$ of coaches and players respectively replied that they do not have enough equipment and facilities for training.

According to the responses gathered from open-ended questions asked about, what is the impact of having insufficient availability of facilities and equipment, most of the respondents responded that not sufficient and it leads to wastage of time to address every single players in the team as much training as every players is needed and also affecting individuals interest for the sport so that it decrease number of potential players.

Regarding sportswear for training and competition, $66.7 \%$ and $76.6 \%$ of coaches and players respectively answered that they do not have the appropriate sportswear for training and for competition separately. Whereas $33.3 \%$ and $23.4 \%$ of coaches and players respectively replied that they have the appropriate sportswear for training and for competition separately.

According to the responses gathered from open-ended questions asked about, what is the impact of having insufficient or no sportswear, most of the respondents responded that not sufficient most of the players train and 
compete with bare foot and with the dresses which is not appropriate for football sport and also in the competition one cannot identify easily which one of the player is in which team and it leads to decrease the interests of the player, coaches and spectators of the sport.

Regarding food after training and competition, 86.7\% and $81.9 \%$ of coaches and players respectively answered that their project or team do not provide sufficient food after training and competition. Whereas $13.3 \%$ and $18.1 \%$ of coaches and players respectively replied that their project or team provides sufficient food after training and competition.

As for the responses gathered from open-ended questions asked about, what is the impact of having insufficient food after training and competition, most of respondents responded as having insufficient food totally decreases physical fitness and interest for the sport.

According to Jackson (1986) underscored that energy intakes peaked between age 16 and 29 years and then decline for succeeding age groups. A similar pattern occurred for males and females, although males reported higher daily energy in takes than female at all ages between age 20 and 29 years, the women consumed on average $35 \%$ fewer kcal than men on a daily basis, ... Individuals who engage regularly in moderate-to- intense physical activity eventually increase daily energy intake to match their higher energy expenditure level.

Regarding regular incentive $86.5 \%$ and $53.3 \%$ of respondents of players and coaches respectively answered that their project or team does not provide them with regular incentives for their career. Whereas $46.7 \%$ and $13.5 \%$ of coaches and players respectively replied that their project or team provides regular incentives for their career.

According to the responses gathered from open-ended questions asked about, what is the impact of having insufficient or no incentives, most of the respondents responded that not sufficient or no incentive and it leads to find another job so we considered the sport as a leisure time activity instead of full time work because of this football sport declines in our zone.

Thus, this indicates that majority of respondents have no transportation, equipment and facilities, sportswear, food and regular incentives for their work. This could be one of the problems for the development of football in North Sowa Zone.

\section{Discussion}

According to the responses of the research participants, it is so easy to understand that there was consistency of views on the issues that rose by the researchers. At this juncture, it is also important to remind that considerable numbers of respondents were complaining about the problems of football in North Showa Zone.

One of the major possible factors which have got quite a significance number of respondents' attention was poor practice of talent identification. There is no scientific method of talent identification in North Showa Zone football sport,
Related to this, Helsen et al. (2000), \& Elferink- Gemser et al. (2007) argued that the selection and orientation of talent has been strongly dependent on biological and motor variables, although these variables are not able to fully differentiate athletes by competitive levels.

In the same manner, the result of correlation analysis on the number of clubs clearly represents that there is high relationship between the responses of coaches and sport office officers on these Structure of clubs, from 1970s to end of 1980, there was many strong clubs in this era like Debre Birhan Blanket Factory, Terbi (Special Force), $16^{\text {th }}$ KefeleTore, Awera Godana, Beresa, Birhan Teachers, Negadea, Teachers Training (Temiro Mastemar), Kefitegna and, and Kefitegna hulet this two teams i.e. Kefitegna and \& Kefitegna hulet in 1975/6 formed as one that is Debre Birhan Kenema. And there are also many other strong clubs from end of 1980s to mid of 1990, in this era like Birhan teachers, Tumbaho monopoles in shewa Robit, Deber Birhan Teachers Training Collage, Soldiers, Debre Birhan Kenema, St. giorgise, police, Negadea, Ersha Sebel, and Debre Birhan Blanket Factory. Debre Birhan Blanket Factory was Amara region champion in 1992 in the next year i.e. in 1993 this club take part in national league competition and also this club get the chance to compete with Buna club. The other club Debre birhan Kenema ranked third in the competition that held in Amara region and this club in the next year 1995 take part in national league competition. Even though Debre Brihan Kenema joins national league competition but cannot proceed to compete in the primer league level.

In the present time from those strong football clubs in the zone we found only Debre Birhan Kenema

\section{Conclusion}

Based on the data collected and the discussions made, the major challenges associate with the development are lack of adequate facilities and balanced diet, very low media coverage, disorganized youth project, very few number of sponsors, very few number of spectators, absence of organized club supporters, absence of transportation, the absence of regular skill development courses for coaches, insufficient remuneration for coaches and players, shortage of field for training and competition, losing popularity, a few number of teams, and incapacity of competence and skills of match referees. In this respect, participants indicated that the sport office should work hand to hand with all stakeholders is completely necessary.

\section{Acknowledgements}

First and foremost, we would like to thank the almighty God for being there in all our endeavors and we would like to express our sincere gratitude and appreciation to Debre Birhan University. This project couldn't have been completed without the tremendous contributions of Debre Birhan University sport science department staff members, M/r G. Micael Fisiha natural and computational college research and 
community service facilitator, $\mathrm{M} / \mathrm{r}$ Tsega Mesfin, $\mathrm{M} / \mathrm{r}$ Dereje Aschenaki, M/r Melkamu Dugassa we are also thankful to the research participants who showed their unreserved collaboration in giving us the necessary information.

\section{References}

[1] Bompa, T. O (1999). Periodization: theory and methodology of training. Champaign: Human Kinetics.

[2] Bompa, T. O (1994). Theory and methodology of training: the key to athletic training. Champaign: Human Kinetics.

[3] David Levinson and Karen Christensen 2005 Berkshire Encyclopedia of World Sport Volume-2 Berkshire Publishing Group LLC U.S.A

[4] Elliot, F. R. 1988. The Family: Change and Continuity. London: MacMillan Education.

[5] Eileen Kennedy and Laura Hills (2009), Sport, media and society Ed Berg

[6] Elaine Wolstencroft (ed.) August 2002 Talent Identification and Development: A report for sportscotland by The University of Edinburgh

[7] Ewing, M. E., \& Seefeldt, V. (1989). Participation and attrition patterns in American agency-sponsored and interscholastic sports: An executive summary Final Report.

[8] Gould, D. \& Petlichkoff, L. (1988) Participation motivation and attrition in young athletes, In F. L. Smoll, R. A. Magill, \& M. J. Ash (Eds.), Children in sport ( $3^{\text {rd }}$ ed.). Champaign IL: Human Kinetics.

[9] Kruger, R. A. 1998. Analyzing and reporting Focus Group Results. Thousands Oak Sage.
[10] Leedy, P. D. 1991. Practical Research, Planning and Design. New Jersey. Prentice-Hall.

[11] Lindsey, L. L \& Beach, S 2000. Sociology. Social Life and Social Issues. New Jersey. Prentice-Hall.

[12] McNeill, P. 1990. Research Methods. Second Edition. London and New York. Rout edge

[13] Malina, R. M., \& Cumming, S. P. (2003): Current status and issues in youth sports. In R. M. Malina \& M. A. Clark (Eds.), Youth sports: Perspectives for a new century. (pp. 7-25).

[14] Ministry of Youth, Sport and Culture (1998): National Sport Policy of Ethiopia. Addis Ababa: Bole Printing Int.

[15] Morrow, S. (2003) The People's Game? Football Finance and Society Basingstoke; Palgrave- Macmillan

[16] Nachmias, C and Nachmias, D. 1981. Research Methods in Social Sciences. New York. Worth Publishers.

[17] Neuman, W. L. 2000. Social Research Methods Qualitative and Quantitative Approaches. Boston. Allyn and Bacon.

[18] Nicholson, M (2007), Sport and the media: managing the nexus. Sport Management Series

[19] Rosen, S. and Sanderson, A. (2001) Labor markets in professional sports The Economic Journal, 111: 47-68.

[20] Seefeldt, V., Ewing, M., \& Walk, S. (1992) Overview of youth sports programs In the United States Washington, DC: Carnegie Council of Adolescent Development

[21] Sharkey, B. (2002). Fitness \& health (5th ed.). Champaign, IL: Human Kinetics.

[22] Weiss, M. R., \& Stuntz, C. P. (2004). A little friendly competition: Peer relationships and psychosocial development in youth sports and physical activity contexts. (pp. 165-196). 